\title{
Bibeloversættelse som selvhjælp
}

\section{Jesper Høgenhaven}

Jette Holm, Helge Kjær Nielsen og Ruth Østerby: Nypagts-Bogen. Grundtvigs nytestamentlige oversattelser. Skrifter udgivet af Grundtvig-Selskabet XLI, Fønix 2018: Palmeserien 11, 288 sider, 250 kr.

Grundtvigs indsats som oversætter af oldnordiske og angelsaksiske tekster er velkendt og tilskrives en central plads i hans biografi og værk. Mindre kendt er hans arbejde med at gengive bibeltekster. Det er ikke så sært; for Grundtvigs bibeloversættelser er for størstedelen aldrig blevet trykt, men foreligger kun i manuskriptform. En undtagelse er de oversættelser af nytestamentlige tekststykker, som ledsager Grundtvigs prædikener. Det er en af disse Grundtvig-oversættelser fra Christelige Pradikener eller Søndags-Bog (1827-1830), der fik en nedladende bemærkning med på vejen fra Kierkegaard i Philosophiske Smuler:

Men skulle en saadan triumpherende Generation, der drager gjennem Livet med Sang og Klang, som Du siger, og hvorved Du, hvis jeg ikke husker feil, erindrer mig om et ikke ubekjendt Genies burschikose og ølnordiske Oversættelse af et Bibelsted, skulle den virkelig være troende?

Grundtvig havde her gengivet nogle ord fra Ef 5,19: "saa der hos Eder er Sang og Klang af Hjertens-Grund for Herren”. Faktisk er denne gengivelse af den nytestamentlige tekst kendetegnende for Grundtvigs bestræbelse på som oversætter at skabe et kraftfuldt og prægnant dansk udtryk, der lige præcis fanger "klangen" i originalteksten og formidler den videre i en ny sproglig kontekst.

Det er særdeles fortjenstfuldt, at Holm, Kjær Nielsen og Østerby med denne udgivelse trækker denne lidt underbelyste side af Grundtvigs arbejde frem. Det sker først og fremmest i form af en samlet offentliggørelse af Grundtvigs oversættelser af tekster fra Det Nye Testamente, hvoraf langt de fleste her trykkes for første gang. 
Bogens indledende afsnit, der sætter bibeloversættelserne ind i en biografisk ramme, præsenterer en ganske overbevisende tese om den rolle, det nytestamentlige oversættelsesarbejde synes at have spillet i Grundtvigs liv. På et tidligt tidspunkt (1815-16) giver Grundtvig udtryk for, at han har til hensigt at kaste sig ud i en samlet dansk bibeloversættelse, et projekt, han imidlertid senere opgiver, antagelig fordi han fandt sine egne hebraiskkundskaber utilstrækkelige. Hvad de nytestamentlige oversættelser angår, viser det sig, at de først og fremmest er udarbejdet i tre adskilte perioder, nemlig i tidsrummet $1810-1820$, i 1844 og endelig i 1853 . Og her peger indledningen på, at Grundtvig på et tidspunkt under sin dybe krise i 1810-11 får det råd af en læge at fordybe sig i oversættelse som en måde at håndtere sin nedtur. Og i hvert fald når man går frem til 1853, kunne det se ud til, at her var et mønster, der gentager sig i Grundtvigs liv. I sommeren 1853, hvor Grundtvig opholder sig hos hustruen, Marie Toft, på Rønnebæksholm, gennemlever han igen en periode med tungsind og energiforladthed; og det giver god mening at se hans arbejde med nytestamentlige oversættelser i dette lys; og en tilsvarende sammenhæng kan der argumenteres for, hvad angår foråret 1844. For Grundtvig ser det med andre ord ud til at have været en form for terapi eller selvhjælp at oversætte Det Nye Testamente til dansk, en overlevelsesstrategi, som han griber tilbage til flere gange i sit liv.

Som forfatterne er inde på, stiller det naturligvis Grundtvigs nytestamentlige oversættelser i et særligt lys. De er således næppe blevet til med henblik på offentliggørelse, eller de er i det mindste kun ufærdige forarbejder og må bedømmes på disse forudsætninger. Grundtvig vender i flere tilfælde tilbage til de samme bibeltekster og gengiver dem ofte ganske forskelligt, hvad der tyder på, at ord og udtryk i høj grad er noget, der kommer til ham i selve processen med at oversætte. Denne procesorienterede arbejdsform passer godt til oversættelsesarbejdets karakter af selvhjælp i Grundtvigs egen kamp for afklaring og åndelig lindring.

Det er selvfølgelig stadig relevant at se, hvordan Grundtvig går til den græske tekst, og hvilke sproglige og stilistiske virkemidler han benytter sig af for at bringe tekstens indhold til udtryk på dansk. I et udførligt tredje afsnit (efter den biografiske indledning og Grundtvigs tekster) får vi en sproglig vurdering af Grundtvigs oversættelser set i forhold til den samtidige danske bibeltradition, ikke mindst den reviderede oversættelse af 1819. Generelt viser Grundtvig sig som en selvstændig og forholdsvis 
frit arbejdende oversætter. Mest traditionsbunden er han i de tidlige gengivelser af perikopetekster i prædikensamlingerne, om end Søndags-Bogen (hvor Ef 5,19 altså indbragte ham Kierkegaards hån) her skiller sig ud med sine friere, undertiden mere parafraserende gengivelser. Man kunne på forhånd have forestillet sig, at ændringen i Grundtvigs bibelsyn omkring 1825 og hans "mageløse opdagelse" ville have afsat et tydeligere præg i hans måde at oversætte på; men det ser ikke ud til at være tilfældet. Det er ikke sådan, at Grundtvig påviselig bliver friere eller mindre tekstnær efter dette tidspunkt. Derimod havde Grundtvig sit eget syn på den nytestamentlige tekstkritik: I en artikel fra 1837 gjorde han gældende, at den eneste forsvarlige nytestamentlige tekst var den, der fandtes i Complutenserbibelen, og at denne derfor måtte foretrækkes frem for "textus receptus”; og han var særdeles kritisk mod J.J. Griesbachs tekstudgave fra 1827 (se også Jette Holms artikel i Grundtvig-Studier 2017). Det er da også Complutenserbibelens tekst (eller "Alcala-teksten"), han generelt lægger til grund for sine oversættelser.

Forfatterne har med bogen her gjort både Grundtvig-forskningen og studiet i dansk bibeloversættelseshistorie en solid tjeneste, som de har ære af. 